\title{
PEMBELAJARAN ANTROPOLOGI BUDAYA PADA MATA PELAJARAN IPS
}

\author{
Syifa Evania Farin \\ Email: Syifaevania08@gmail.com \\ Program Studi Pendidikan Ilmu Pengetahuan Sosial Fakultas Keguruan dan Ilmu \\ Pendidikan \\ Universitas Lambung Mangkurat \\ Banjarmasin
}

\begin{abstract}
Abstrak
Antropologi merupakan salah satu ilmu sosial yang terdapat pada mata pelajaran IPS, salah satu cabang dari antropologi ialah antropologi budaya. Antropologi erat kaitannya dengan kebudayaan, yaitu ilmu yang mempelajari tentang manusia dan masyarakatnya, mulai dari adat, kebiasaan, tingkah laku. Antropologi budaya merupakan cabang dari antropolgi yang perkembanganya paling pesat, karena manusia menciptakan perubahan dari waktu ke waktu dan menciptakan kebudayaan dengan akal pikiran, ide-ide dan gagasan dalam kesadaranya.
\end{abstract}

\section{PENDAHULUAN}

Pendidikan pada zaman globalisasi seperti sekarang ini sangat membuat semua orang mudah mengakses berbagai macam informasi. Dengan kemajuan-kemajuan yang semakin berkembang termasuk pada kemajuan ilmu pengetahuan dan teknologi, semua orang dapat dengan mudah memproleh berbagai informasi di manapun. Dengan adanya globalisasi ini juga memberikan manfaat bagi manusia. Namun, juga perlu adanya pemilahan serta mencermati dan menyikapinya dengan bijak. Salah satunya dengan cara penyampaian materi antropologi yang tepat kepada peserta didik melalui pembelajaran IPS, salah satu caranya yaitu penanaman nilai dan norma. Melalui pelajaran IPS kita dapat menyampaikan pemahaman mengenai konsep dari nilai dan norma penting dalam masyarakat yang merupakan bagian dari antropologi budaya.

Secara sederhana antrolopogi ialah ilmu yang mempelajari aspek manusia dan kebudayaannya. Antropologi merupakan bagian dari ilmu sosial, ilmu pengetahuan sosial (IPS) adalah sebuah studi yang menerapakan dan menggunakan bahan ilmu-ilmu sosal untuk menganalasisa dan mempelajari hubungan antar manusia dalam aspek masyarakat dan peran manusia yang sebagai anggota masyarakat. Studi sosial merupakan mata 
pelajaran yang ada di sekolah yang tujuannya untuk mempelajari manusia dalam masyarakat yang terjadi pada masa lalu, masa sekarang dan masa yang akan datang.

Pembahasan mengenai budaya dan kebudayaan, ditemui pada pelajaran IPS yang membicarakan atau mendiskusikan kebudayaan sebagai program pendidikan. Antropologi budaya ialah cabang dari ilmu antropologi. Istilah kebudayaan meliputi beberapa aspek cara berfikir dan berprilaku yang hal tersebut merupakan ciri khas suatu Negara, bangsa atau masyarakat tertentu. Oleh kerana itu kebudayaan terdiri dari beberapa aspek diantaranya bahasa, hukum-hukum, ilmu pengetahuan, agama, kepercayaan, makanan khas, kebiasaan mata pecaharian, music, peraturan larangan dan lain sebagainya.

\section{KONSEP DASAR ILMU SOSIAL}

Konsep ialah suatu yang muncul dalam pikiran atau suatu pemikiran, pengeertian dan gagasan. Pengertian lain yaitu konsep merupakan suatu gambaran mental mengenai sesuatu. Seseuatu yang dimaksud dapat berupa objek konkret maupun gagasan yang bersifat abstrak, Dorothy J. Skeel (1979:18). Konsep studi sosial merupakan kata atau ungkapan yang memiliki hubungan dengan sesuatu yang menonjol, dan sifat yang melekat. Penggunaan dan pemahaman konsep yang paling sesuai ialah bergantung kepada penguasaan sifat yang melekat tersebut, James G. Womack (1970:30).

Berdasarkan konsep yang telah dikemukakan tadi, dapat disimpulkan bahwa konsep tidak lain merupakan pengertian yang terpapar atau tergambar dalam pikiran yang mendefinisikan suatu benda atau sebuah gagasan, baik konkrit maupun abstrak. Konsep IPS ialah suatu pengertian mengenai fenomena dan benda yang memiliki kaitan dengan IPS itu sendiri.

Pada dasarnya manusia ialah makluk sosial, yang dimana dapat kita temui kehidupan menusia di masyarakat meliputi berbagai macam aspek. Salah satu aspek yang penting adalah mendefinisikan kemajuan dari kebudayaan, yang dimana semua orang memiliki kecenderungan yang kuat untuk hidup berdampingan dengan yang lain dalam sebuah kelompok. Manusia dalam menjalani kehidupan bermasyarakat di bentuk oleh nalurinya dalam menciptakan budaya untuk mempertahankan diri di dalam kelompoknya. Naluri dan kebudayaan itu dipraktekan dalam upaya mencukupi kebutuhan hidupnya, baik itu jasmani maupun rohami.

\section{ANTROPOLOGI BUDAYA}

Antropologi merupkan suatu ilmu sosial yang mempelajar tentang manusia dari berbagai sudut pandang, mulai dari pola berprilaku dan cara berpikir. Ilmu antropologi memiliki bidang kajian yang amat luas. Antropologi mempelajari tingkat kemajuan dari pola tingkah laku dan cara manusia berfikir yang pada dasarnya hal tersebut selalu mengalami kemajuan, mulai dari sederhana sampai modern, mulai dari manusia pada 
zaman dahulu hingga sekarang selalu ada perubahan. Perubahan yang terjadi bisa membawa dampak negatif maupun positif.

Antropologi ialah ilmu pengtahuan dimana ilmu ini mempelajari manusia sebagai makhluk sosial masyarakat. Tujuan focus dari ilmu pengetahuan ini ada pada sifat khusus badani dan cara produksi, tradisi kebudayaan, dan juga nilai yang membuat pergaulan hidup menjadi pembeda. Secara khususnya kajian dari antropologi ini menelaah atau mengkaji manusia dari sudur perbedaanya dan keanekawarnaanya, yaitu mulai dari berbagai macam warna fisik (raga/tubuh) dan juga tingkah laku dan cara berfikirnya. Antropologi juga melihat masalah manusia biologi dan manusia yang merupakan makhluk sosial yang tidak terpisah, tetapi keseluruhan.

Bidang ilmu antropologi ini mengkhususkan pengamatannya kepada kebudayaan. Secara singkatnya antropologi suatu studi mengenai manusia dengan kerjanya, E.A. Hoebel (Fairchild, H.P. dkk:1982:12). Hobel mengemukakan dengan kerjanya, yang dikemukakan oleh Hobel dengan kerjanya itu dapat diartika sebagai kegiatan pikiran dan suatu pemikiran yang artinya budaya dan kebudayaan. Sehingga pengertia antropologi secara tepat dapat dikatakan antropolgi budaya, Hobel juga mengatakan bahwa antropologi budaya itu merupakan studi mengenai perilaku manusia, Fairchild, dkk: (1982: 12).

Antropologi budaya merupakan bagian dari antropologi yang mempelajari kebudayaan, mulai dari kebudayaan pada umumnya sampai kebudayaan-kebudayaan yang ada di Negara dan bangsa di muka bumi. Menyelidiki dan menelaah bagaimana manusia beradaptasi dengan budayanya dan melakukan pembaruan atau mengembangkan kebudayaan sepanjang zaman. Pengamatannya tertumpu pada magaimana manusia dengan kondisi akal dan fisiknya yang berbeda-beda berhasil mengubah lingkungan yang bukan oleh nalurinya sendiri, melainkan oleh pengajaran dan pemahaman yang memiliki arti luas. Kajian terbesarnya dilakukan melalui perbandingan melalui proses pengamatan, pemahaman budaya dalam masyarakat dan penulisan.

Kebudayaan merupakan keseluruhan dari cara kehidupan dari masyarakat, kebudayaan mengarah pada berbagai aspek kehidupan. Meliputi dari berbagai macam aspek mulai dari cara berprilaku, sikap, kepercayaan, dan ciri khas manusia yang ada pada masyarakat atau kelompok tertentu. Kebudayan pada antropologi menjelaskan bagaimana hubungan timbal balik antara manusia dan kebudayaan dari masa ke masa. Dalam hal ini juga kebudayaan sering dipandang sebagai hasil dari kreasi manusia di salah satu sisi dan kebudayaan tersebut merupakan sarana yang menjadikan manusia untuk dapat hidup diberbagai sisi.

Kebudayaan muncul karena diciptakan oleh manusia agar memenuhi kebutuhannya. Dengan adanya kebudayaan maka lambat laun manusia akan terikat padanya. Dan keterkaitan ini menyebabkan manusia tersebut tidak mungkin lagi bisa hidup tanpa adanya kebudayaan. Hasil dari kreasi ciptaan manusia terwujud secara sistematik dalam bentuk" 
prantara kebudayaan. Kebudayaan merupakan suatu system ide yang berperan sebagai pedoman bagi manusia demi keberlangsungan hidup.

\section{PEMBELAJARAN IPS DAN ANTROPOLOGI}

Tujuan paling utama dari pendidikan IPS ialah menyiapkan dan mempersiapakan peserta didik agar menjadi anggota masyarakat dan warga Negara yang berkualitas serta menyampaikan dasar pengetahuan sosial untuk jenjangnya yang akan datang. IPS merupakan pembelajaran pengetahuan sosial yang bertumpu pada tujuan yang difokuskan agar mengembangkan kemampuan dari peserta didik melalui pengetahuan sosial budaya yang didapat, dengan berbagai macam bentuk mulai dari bentuk kemampuan berfikir, sikap dan kepribadian, dan nilai bagi dirinya sendiri baik itu sebagai perannya untuk individu maupun makhluk sosial budaya. Hasan (Depdiknas, 2006: 101).

IPS atau ilmu pengetahuan sosial ialah ilmu pendidikan yang mempelajari tentang ilmu sosial yang dikembangkan dalam kurikulum akademik dan juga kurikulum disiplin yang diantaranya menggambungkan disiplin ilmu lainnya seperti geografi, ekonomi, sejarah, antropologi, dan sosiologi secara terpisah.

Antropologi merupakan bagian cabang ilmu sosial, antropologi budaya adalah cakupan dari antropologi dan pembahasan ini ada pada mata pelajaran IPS yang merupakan bagian dari program pendidikan. Antropologi dianggap sebagai sebuah mata pelajaran bersamaan dengan mata pelajaran lainya, pelajaran ini diangga wajib dan penting disampaikan kepada peserta didik. Antropologi dipandang sebagai bagian dari kajian ilmu pengetahuan, ada beberapa tuntutan diantaranya menjelaskan ilmu tersebut sebagai kedudukan dalam ilmu yang lebih luas.

Dalam penyampaian materi antropologi seorang pengajar atau guru wajib menguasai konsep, terori, sejarah, dan pengembangan disiplin ilmu antropologi melalui beberapa penelitian, serta kegunaan ilmu antropologi bagi keberlangsungan hidup manusia. Mata pelajaran antropologi ini memiliki tujuan agar peserta didik mempunyai kemampuan diantaranya, memahami dasar antropologi, mengamati dan memecahkan masalah secara kritis serta rasional. Menganai berbagai fenomena sosial budaya.

Adapun ruang lingkup dari pelajaran antropologi ini yakni sebagai berikut; Bahasa, Keragaman budaya, Religi, Seni, dan ilmu pengetahuan dan teknologi. Adapun pengajaran antropologi memiliki beberapa fungsi utama yaitu untuk meningkatkan dan mengembangkan kemampuan analisis berbagai peristiwa kebudayaan di lingkungan masyarakat sendiri, mengembangkan ilmu pengetahuan dan wawasan terhadap budaya sendiri dan budaya masyarakat lain khususnya dalam lingkungan Indonesia, dan mendorong tumbuhnya kesadaran akan kedamaian hidup bersama dalam masyarak. Antropologi sangat diharapkan agar peserta didik mampu menyerap sebagai pengetahuan dan menerapkannya dalam kehidupan sehari-hari, dan yang terpenting dalam menyikapi perbedaan latar budaya, masyarakat, bahasa dan kepercayaan di masyarakat. 


\section{SIMPULAN}

Secara sederhana antrolopogi ialah ilmu yang mempelajari aspek manusia dan kebudayaannya. Antropologi merupakan bagian dari ilmu sosial, ilmu pengetahuan sosial (IPS) adalah sebuah studi yang menerapakan dan menggunakan bahan ilmu-ilmu sosal untuk menganalasisa dan mempelajari hubungan antar manusia dalam aspek masyarakat dan peran manusia yang sebagai anggota masyarakat.

Antropologi budaya merupakan bagian dari antropologi yang mempelajari kebudayaan, mulai dari kebudayaan pada umumnya sampai kebudayaan-kebudayaan yang ada di Negara dan bangsa di muka bumi. Menyelidiki dan menelaah bagaimana manusia beradaptasi dengan budayanya dan melakukan pembaruan atau mengembangkan kebudayaan sepanjang zaman. Pengamatannya tertumpu pada magaimana manusia dengan kondisi akal dan fisiknya yang berbeda-beda berhasil mengubah lingkungan yang bukan oleh nalurinya sendiri, melainkan oleh pengajaran dan pemahaman yang memiliki arti luas. Kajian terbesarnya dilakukan melalui perbandingan melalui proses pengamatan, pemahaman budaya dalam masyarakat dan penulisan.

Antropologi merupakan bagian cabang ilmu sosial, antropologi budaya adalah cakupan dari antropologi dan pembahasan ini ada pada mata pelajaran IPS yang merupakan bagian dari program pendidikan. Antropologi dianggap sebagai sebuah mata pelajaran bersamaan dengan mata pelajaran lainya, pelajaran ini diangga wajib dan penting disampaikan kepada peserta didik. Antropologi dipandang sebagai bagian dari kajian ilmu pengetahuan, ada beberapa tuntutan diantaranya menjelaskan ilmu tersebut sebagai kedudukan dalam ilmu yang lebih luas.

\section{REFERENSI}

Abbas, E. W. (2013). Mewacanakan Pendidikan IPS. Mewacanakan Pendidikan IPS.

Abbas, E. W. (2018). Penguatan Pendidikan IPS Di Tengah Isu-Isu Global.

Anis, M. Z. A., Susanto, H., \& Mardiani, F. (2021, February). Analysis of the Effectiveness of MPBH: The Mains of Mandai as a Saving Food in Banjarmasin Community. In The 2nd International Conference on Social Sciences Education (ICSSE 2020) (pp. 89-94). Atlantis Press.

Mutiani, M., Subiyakto, B., Jumriani, J., Aslamiah, A., \& Afrina, A. (2019). Laporan Penelitian: Relevansi Modal Sosial Dalam Pembelajaran IPS (Studi Kasus Dalam Sistem Zonasi Di Smp Negeri Kota Banjarmasin).

Putro, H. P. N., \& Jumriani, J. (2020). KEHIDUPAN SOSIAL DAN EKONOMI MASYARAKAT BANTARAN SUNGAI A SEBAGAI SUMBER BELAJAR IPS. 
Susanto, A. T., \& Muhyadi, M. (2016). PERAN KEPALA SEKOLAH DALAM PENGEMBANGAN KOMPETENSI GURU DI SEKOLAH MENENGAH PERTAMA NEGERI. Jurnal Akuntabilitas Manajemen Pendidikan, 4(2), 151-163.

Susanto, H. (2020). PEDAGOGI SEJARAH, NASIONALISME DAN KARAKTER BANGSA. Preprint: EdArxiv.

Susanto, H. (2020). Profesi Keguruan. Banjarmasin: FKIP Universitas Lambung Mangkurat.

Susanto, H., Irmawati, I., Akmal, H., \& Abbas, E. W. (2021). Media Film Dokumenter Masuknya Islam Ke Nusantara dan Pengaruhnya Terhadap Keterampilan Berpikir Kritis Siswa. HISTORIA: Jurnal Program Studi Pendidikan Sejarah, 9(1).

Syaharuddin, S., Hidayat Putra, M. A., \& Susanto, H. (2019). Nilai Budaya Manyambang Masyarakat Desa Lok Baintan Dalam Sebagai Sumber Belajar IPS.

Taneo, S. P. KONSEP DASAR ILMU-ILMU SOSIAL.

Wiranata, I. G. A., \& SH, M. (2011). Antropologi budaya. Citra Aditya Bakti. 